\title{
ANCHORING TO THE EURO (AND GROUPED TOGETHER)? THE CASE OF AFRICAN COUNTRIES
}

\begin{tabular}{rcc}
\hline João Loureiro & Manuel M. F. Martins & Ana Paula Ribeiro \\
loureiro@ fep.up.pt & $\underline{\text { mmfmartins @ fep.up.pt }}$ & $\underline{\text { aribeiro@ fep.up.pt }}$ \\
CEF.UP* and Faculdade de Economia, Universidade do Porto \\
Rua Dr. Roberto Frias s/n, 4200-464 Porto, Portugal
\end{tabular}

\section{October 2010}

\begin{abstract}
The currencies of sixteen African countries, namely those belonging to the West African Economic and Monetary Union (WAEMU), to the Central African Economic and Monetary Community (CAEMC), Comoros and Cape Verde, have been pegged to the euro since the inception of the new European currency in 1999. This paper assesses whether the euro is an adequate anchor for those countries. The evaluation is based on three key criteria borrowed from the optimal currency area (OCA) theory and the conclusion is that the euro is an appropriate currency for anchoring only in the case of Cape Verde. Since the members of WAEMU and of CAEMC are jointly pegged to the euro, the paper further assesses whether the grouping of countries in these two CFA monetary unions receives economic support. Based on the OCA criteria used to investigate the first issue, the conclusion is that the composition of CAEMC does not conform to basic requirements. In contrast, for a wide group of WAEMU countries there is room for sharing a common monetary policy.
\end{abstract}

Keywords: WAEMU, CAEMC, Comoros, Cape Verde, Euro, Optimal Currency Area. JEL classification: E32, F15, F33.

* CEF.UP - Centre for Economics and Finance at University of Porto - is supported by the Fundação para a Ciência e a Tecnologia (FCT), Portugal. 


\section{Introduction}

Sixteen African countries have their currencies pegged to the euro since the inception of the European Monetary Union (EMU) in 1999. Among them, Cape Verde and Comoros have their own central banks and their own currencies, the Cape-verdian escudo and the Comorian franc, respectively. The remaining countries are grouped in two monetary unions, each with a common currency issued by a single central bank. Benin, Burkina Faso, Ivory Coast, Guinea-Bissau, Mali, Niger, Senegal and Togo form the West African Economic and Monetary Union (WAEMU) and the Banque Centrale des Etats de l'Afrique de l'Ouest (BCEAO) is their central bank. Cameroon, Central African Republic, Chad, Republic of Congo, Equatorial Guinea and Gabon form the Central African Economic and Monetary Community (CAEMC), whose central bank is the Banque des Etats de l'Afrique Central (BEAC). ${ }^{1}$ Although issued by separate central banks, the currencies of WAEMU and CAEMC are both known as CFA franc and they have the same parity against the euro. Each CFA franc is legal tender only in its

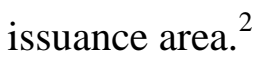

Now, when more than a decade has elapsed since the beginning of the new peg, an assessment of its adequacy is both feasible and pertinent. This is one of the main purposes of this paper and is carried out in section 2. We address the issue providing an economic assessment based on key criteria borrowed from the optimum currency areas (OCA) literature. Motivated by the results of section 2, we additionally assess the grouping of countries in the two regional African monetary unions currently pegged to the euro. This exercise is carried out in section 3, by using the same empirical strategy. Finally, in section 4 we summarize the results and point out some concluding remarks.

The remaining of this introduction fulfills three objectives. First, we briefly describe some institutional details of the exchange-rate regimes of the African countries that

\footnotetext{
${ }^{1}$ The WAEMU and the CAEMC are also known by the French acronyms UEMOA and CEMAC, standing, respectively, for Union Economique et Monetáire Ouest Africaine and Communauté Économique et Monétaire de l'Afrique Centrale.

${ }^{2}$ Until independence, the acronym CFA stood for Colonies Française de l'Afrique. Since then, CFA stands for Communauté Financière Africaine in the case of WAEMU and Cooperation Financière en Afrique Centrale in the case of CAEMC.
} 
have their currencies pegged to the euro. Second, we motivate and introduce the empirical strategy adopted in the assessments carried out in sections 2 and 3. Third, we highlight the main contributions of our paper and we relate it to the existing literature.

\section{Institutional framework}

The current peg to the euro is, in all the sixteen African countries, a continuation of previous fixed exchange rate arrangements having as reference European currencies that were replaced by the euro in 1999. The Cape-verdian escudo was previously pegged to the Portuguese escudo, while the Comorian franc and the CFA francs were pegged to the French franc.

When the French franc and the Portuguese escudo were about to be replaced by the euro, the European Council has formally authorized the continuance of the exchange rate arrangements in force between the African countries and France and Portugal. ${ }^{3}$ With the changeover to the new reference currency, no realignment took place. Accordingly, the new parities were set at the crossed exchanges rates that both the Portuguese escudo and the French franc were converted into euro and they have been fixed now for more than ten years. ${ }^{4}$

In the case of the fifteen African countries belonging to the franc zone, the peg is part of foreign exchange cooperation agreements signed with France in 1972 and 1973. The main elements of the agreements are the following:

- a fixed parity with reference to the French franc/euro (the only realignment occurred in 1994, when the CFA franc was devalued by 50 per cent and the Comorian franc was devalued by 33 per cent);

- no restrictions to capital movements within each CFA franc monetary union and with France;

- unlimited convertibility guarantee for the CFA and Comorian francs, provided by the French Treasury;

\footnotetext{
${ }^{3}$ For the legal details of the authorization of the European Council see, for example, Lamine (2006).

4 The fixed exchange rates are 655.957 CFA francs, 491.96775 Comorian francs and 110.265 Capeverdian escudos per euro.
} 
- pooling of the foreign reserves of the members of each monetary union at the union's central bank;

- transfer of part of the net foreign reserves of the BCEAO, the BEAC and the central bank of Comoros to Operations Accounts managed by the French Treasury. ${ }^{5}$

Although in theory the central banks of the African franc zone have access to unlimited financing from the French Treasury, the agreements contain provisions preventing the likelihood of such event. In particular, when the balance of the Operations Accounts reaches critical figures, measures are taken to improve it (e.g., increase in the central bank interest rates).

In the case of Cape Verde, the peg is part of a foreign exchange cooperation agreement established in 1998 with Portugal. As part of the agreement and in order to support the fixed exchange rate system, the Portuguese Treasury provides Cape Verde with a limited credit facility in Portuguese escudos (now in euros), at a concessional interest rate.

\section{Empirical strategy}

The OCA theory has developed some criteria that are useful for assessing the adequacy of a fixed exchange rate system. ${ }^{6}$ In this paper we follow Alesina and Barro (2002) and focus on three of the most relevant: the degree of trade integration, inflation performance, and the correlation of business cycles. As theoretically shown by Alesina and Barro (2002), the type of country that gains more by joining a monetary union is (i) a small open economy that trades heavily with the members of the union, (ii) with a history of high inflation, and (iii) with a business cycle highly correlated with the cycle of the union. Most of the reasons that make these criteria decisive for participation in a monetary union also apply for adhering to a fixed exchange rate system. In particular,

\footnotetext{
5 "Compte d'Opérations" is a sort of current account in French francs (now in euros) comprising overdraft facilities. The deposits at the operations account are subject to minimum amounts. These amounts have been gradually reduced. Currently, the African franc zone central banks have to deposit at the French Treasury at least 50 per cent of their net holdings of foreign reserves.

${ }^{6}$ For a survey of the OCA literature see, inter alia, Mongelli (2005).
} 
(i) Pegging to the currency of the main partners reduces exchange rate risk, which encourages international trade and foreign investment. ${ }^{7}$ It is true that, by pegging, a country gives up the use of the exchange rate for demand management purposes, which may be seen as a cost. However, for the case of small open economies, which typically have low product diversification, the exchange rate is an instrument with weak effectiveness due to the high pass-through from import prices to domestic prices.

(ii) Adopting a fixed exchange rate provides "the advantage of tying one's hands" (in the words of Giavazzi and Pagano, 1988). By pegging to a currency issued by a central bank with a good anti-inflationary reputation, a country is forced to follow the sound monetary policies of the anchor, thus being able to achieve low rates of inflation.

(iii) A country with a fixed exchange rate regime gets the benefits mentioned in (i) and (ii), but faces the potential cost of losing monetary policy autonomy, namely becoming unable to use the interest rate to smooth output fluctuations. However, this is only a relevant cost if output fluctuations are not synchronized with those of the anchor economy. In case they are synchronized, the monetary policies of the anchor will fit the needs of the pegged countries. Furthermore, in case of, say, a synchronized economic slowdown in both the anchor and the pegged countries will lead to a common decrease in interest rates which, in turn, will lead to an exchange rate depreciation against third countries, improving net exports.

The empirical evidence clearly suggests that developing countries with fixed exchange rate regimes benefit from lower inflation rates, as compared with countries with more flexible regimes. Among others, this is documented by Bleaney and Fielding (2002) for the CFA franc countries. The updated descriptive statistics for the post-1999 period displayed in section 2 confirm that, in fact, the African countries that have been pegged to the euro display a better inflation performance than the rest of the continent. In short, the African euro trackers seem to have achieved the benefit described in (ii) above. Yet, inflation performance is not the only decisive criterion for judging whether the peg to the euro is an adequate option. In fact, even assuming that exchange rate pegging is the only available strategy for African countries to achieve price stability, one can think of

\footnotetext{
${ }^{7}$ This benefit is enhanced in a monetary union, where the exchange rate risk fully vanishes, the same applying to foreign exchange transaction costs.
} 
alternative anchors (e.g., the USD or the SDR) ${ }^{8}$ Hence, we focus our assessment on criteria (i) and (iii), i.e., trade intensity with the Euro Area and synchronization of business cycles. Recently, Meissner and Oomes (2009) came to the general conclusion that for countries that decide to peg their exchange rate, the two criteria are key determinants in the choice of the anchor. Our investigation uncovers if such rationale also applies to the sixteen African countries that are currently pegged to the euro.

The empirical application of the Alesina-Barro framework is problematical however, as the theory is mute regarding the minimum level of trade integration and output correlation required for choosing an anchor currency. Our empirical strategy consists of adopting, as an ad hoc benchmark, the historical values for these two indicators recorded during the same period for twelve members of the EMU (the eleven countries that founded the union in 1999, plus Greece). These countries have had their exchange rates fixed to the euro since they joined the EMU, at the conversion rates with which they have replaced domestic currencies (along the paper we will interchangeable call this set of countries EMU12 and Euro Area). ${ }^{9}$ The EMU12 is used as a reference in a graphical representation similar to Frankel's (1999), which effectively summarizes criteria (i) and (iii).

As the main conclusion from the individual analyses is that the peg to the euro has not been adequate for most of the countries under investigation, we then consider the optimality of the regional monetary unions to which most of them belong. In fact, fourteen countries in the sample did not decide the peg to the euro on an individual basis; rather, that decision resulted from their participation in a monetary union (WAEMU or CAEMC) that had as anchor a currency that joined the euro. This, plus the argument that "the franc zone is largely the result of a historical accident" (Fielding, 2005), motivates the analysis conducted in section 3, where we assess whether there is

\footnotetext{
${ }^{8}$ The most common strategies for achieving price stability are exchange rate pegging, central bank independence and inflation targeting. It is widely acknowledged that for developing countries only the first strategy is actually available.

${ }^{9}$ The 11 founders of EMU are Austria, Belgium, Finland, France, Germany, Ireland, Italy, Luxembourg, Netherlands, Portugal, and Spain. Greece joined EMU in 2001 but it kept the exchange rate of the drachma fixed to the euro between 1999 and 2001. Currently, the EMU is formed by sixteen countries. Slovenia joined in 2007, Cyprus and Malta in 2008 and Slovakia in 2009.
} 
economic support for the current grouping of countries in the two CFA monetary unions. Again, we base the assessment of the optimality of the two CFA monetary unions on Alesina-Barrro's criteria (i) and (iii) - the degree of intra-union trade and the correlation of business cycles of each country with the aggregate business cycles of the corresponding union. As previously, we then use as an ad-hoc benchmark the corresponding records for the EMU.

\section{Related literature and contribution}

To the best of our knowledge, this paper is the first to appraise whether the euro is an adequate anchor for the set of African countries that in 1999 shifted their pegs to the new European currency - the issue that we address in section 2. Research on this matter for the pre-euro period is not abundant and has taken different approaches. The most common one has been the analysis of the properties of real exchange rates - see, e.g., Coleman (2008).

Assessing the optimal gathering of countries in a monetary union - the issue that we address in section 3 - has been receiving a lot of attention, which is extensively reflected in the literature. In the particular case of Africa, different perspectives have been adopted. Some studies have analyzed the use of a single currency in the whole continent (see, e.g., Masson and Pattillo, 2004a, Karras, 2006, and Tapsoba, 2009). Some others have checked whether OCA requirements apply to existing regional economic areas, to enlargements of existing regions and to projected union areas. Examples of such assessments are found in Masson and Pattillo (2001), Debrun, Masson and Pattillo (2003, 2005, 2010), Khamfula and Huizinga (2004), BénassyQuéré and Coupet (2005), Buigut and Valev (2005, 2006), Buigut (2006), Yehoue (2006), Houssa (2008), Masson (2008), Tsangarides and Qureshi (2008), and Carmignani (2009). ${ }^{10}$

In our analysis, we focus exclusively on the WAEMU and on the CAEMC and check whether they are optimal monetary unions, using data only for the recent period of their peg to the euro. The investigation that most closely relates to ours is Bayoumi and Ostry

\footnotetext{
${ }^{10}$ Tavlas (2009) provides an excellent survey on the creation of a monetary union in Southern Africa.
} 
(1997), in the sense that common evaluation criteria are applied to the CFA franc zone. Besides the use of updated data, our investigation differs slightly from theirs in that we do not look at the CFA franc zone as a single arrangement but, rather, as two separate monetary unions as, indeed, they officially are.

Our paper further contributes to the literature by using Frankel's (1999) diagram in an empirical assessment. In fact, the well-known diagram relating trade integration with business cycles synchronization as joint criteria for assessing the appropriateness of a common monetary policy has been only used to set a theoretical frontier.

\section{Has the euro been a suitable anchor?}

In order to assess whether the euro has been an adequate anchor for the current African peggers, in this section we look at the performance of the sixteen African countries vis$a$-vis the Euro Area as regards inflation, trade integration and synchronization of business cycles. ${ }^{11}$ The analysis covers the period $1999-2008 .{ }^{12}$

\section{Inflation}

For the period of the peg to the French franc, Bleaney and Fielding (2002) found that the exchange rate regime helped the CFA countries to achieve significantly lower levels of inflation than the typical floating-rate developing country (although at the cost of higher macroeconomic volatility). As Table 1 shows, such conclusion seems to hold also for the period of the peg to the euro. The table displays the averages and standard deviations of the inflation rates of the sixteen countries for the period 1999-2008. For

\footnotetext{
${ }^{11}$ Our analysis implicitly assumes that the monetary policy of the sixteen countries in our sample closely followed the EMU policy. However, it could be argued that capital controls allow for autonomous monetary policies. While this argument cannot be fully set aside, Veyrune (2007) notes that in 1994 occurred a structural shift in the franc zone, which led to decreasing monetary autonomy. Shortland and Stasavage (2004) also come to the conclusion that monetary autonomy in the franc zone is limited and that short term central bank rates of the anchor (first the Banque de France and now the European Central Bank) have key influence on the monetary policy of WAEMU.

${ }^{12}$ We exclude 2009 from the sample period, for two reasons. First, to avoid as much as possible the noise related with the recent global financial and economic crises, which have been transmitted from the developed world into the emerging countries, albeit with some lag. Second, to minimize the use of data that are still preliminary estimates (some of the data for African countries from 2009 onwards are still reported by the sources as such).
} 
comparative purposes, the table includes the corresponding values for the EMU12, the sub-Saharan Africa, and the whole continent of Africa.

Table 1. Average and standard deviation of inflation rates, 1999-2008

\begin{tabular}{|c|c|c|c|c|}
\hline \multirow[b]{2}{*}{ Country/Region } & \multicolumn{2}{|c|}{ Inflation rate $(\%)$} & \multicolumn{2}{|c|}{ Inflation differential vs EMU (pp) } \\
\hline & Average & $\begin{array}{l}\text { Standard } \\
\text { deviation }\end{array}$ & Average & $\begin{array}{l}\text { Standard } \\
\text { deviation }\end{array}$ \\
\hline EMU12 (a) & 2.46 & 0.73 & - & - \\
\hline Africa & 9.18 & 2.30 & 6.72 & 2.21 \\
\hline Sub-Saharian Africa & 10.76 & 2.98 & 8.30 & 3.06 \\
\hline Cape Verde & 2.32 & 3.02 & -0.14 & 2.95 \\
\hline Comoros & 4.00 & 1.38 & 1.54 & 1.10 \\
\hline WAEMU $^{(a)}$ & 2.65 & 3.21 & 0.19 & 2.87 \\
\hline Benin & 3.17 & 2.36 & 0.71 & 1.98 \\
\hline Burkina Faso & 2.66 & 3.70 & 0.20 & 3.31 \\
\hline Guinea-Bissau & 2.94 & 4.32 & 0.48 & 3.97 \\
\hline Ivory Coast & 2.73 & 1.90 & 0.27 & 1.58 \\
\hline Mali & 2.24 & 3.98 & -0.22 & 3.65 \\
\hline Niger & 2.51 & 4.29 & 0.05 & 3.90 \\
\hline Senegal & 2.28 & 2.08 & -0.18 & 1.83 \\
\hline Togo & 2.69 & 3.05 & 0.23 & 2.70 \\
\hline CAEMC $^{\text {(a) }}$ & 3.15 & 3.80 & 0.69 & 3.67 \\
\hline Cameroon & 2.70 & 2.15 & 0.24 & 2.04 \\
\hline Central African Republic & 2.98 & 3.45 & 0.52 & 3.09 \\
\hline Chad & 1.87 & 7.12 & -0.59 & 6.79 \\
\hline Equatorial Guinea & 5.04 & 2.47 & 2.58 & 2.28 \\
\hline Gabon & 3.46 & 5.92 & 1.00 & 6.23 \\
\hline Republic of Congo & 2.84 & 1.68 & 0.38 & 1.57 \\
\hline
\end{tabular}

Sources: International Monetary Fund, World Economic Outlook Database, April 2010, available at http://www.imf.org/external/ns/cs.aspx?id=28 (accessed in May 2010); values for the aggregates Africa and Sub-Saharan Africa are from the International Monetary Fund, International Financial Statistics (IFS).

Note: (a) Simple (un-weighted) average across member countries.

In general, the sixteen African countries that have been pegged to the euro recorded quite low levels of inflation. Four of them (Cape Verde, Mali, Senegal and Chad) show average inflation rates that are even lower than the average of the Euro Area. Thirteen African countries, out of the sixteen in the sample, display inflation differentials vis- $a$ vis the Euro Area that are less than 1 percentage point. The remaining three countries (Gabon, Comoros and Equatorial Guinea) have had average inflation differentials slightly higher, but nevertheless visibly lower than those observed for aggregate Africa and aggregate sub-Saharan Africa. 
The inflation rates of the countries pegged to the euro have had a substantial volatility, but not much higher than the volatility recorded by aggregate Africa and sub-Saharan Africa. Hence, the unavailability of the exchange rate to accommodate supply and demand shocks has not led the African countries pegged to the euro to suffer from a markedly higher degree of inflation variability.

Overall, the results described in Table 1 are consistent with the hypothesis that the peg to the euro has granted a good inflation performance. However, from the behavior of inflation alone it is not possible to draw the conclusion that the euro has been an adequate anchor for the countries under analysis. Anchoring to the USD, the SDR or any other basket of currencies issued by low-inflation developed countries would, very likely, lead to a similar inflation performance. Thus, in order to assess whether the euro has been an appropriate anchor, we now look at the other two key criteria: trade integration with Euro Area countries and the synchronization of business cycles.

\section{Trade integration}

In Table 2 we provide the degree of trade integration of the African countries that are pegged to the euro. Trade integration is measured as the sum of imports and exports of goods and services, divided by twice the GDP. For comparative purposes, the table also presents the (simple) average of the EMU12 countries. The figures reported in column I measure only exports to and imports from the Euro Area, providing the degree of openness relative to EMU12. Column II reports the total degree of openness to the World, i.e., accounts for total exports and imports of each country. The third column displays the proportion of trade with EMU12 in total trade. Due to data scarcity, the figures reported in Table 2 refer to the period 2002-2007. The figures are averages over the period. 
Table 2. International trade in goods and services, 2002-07

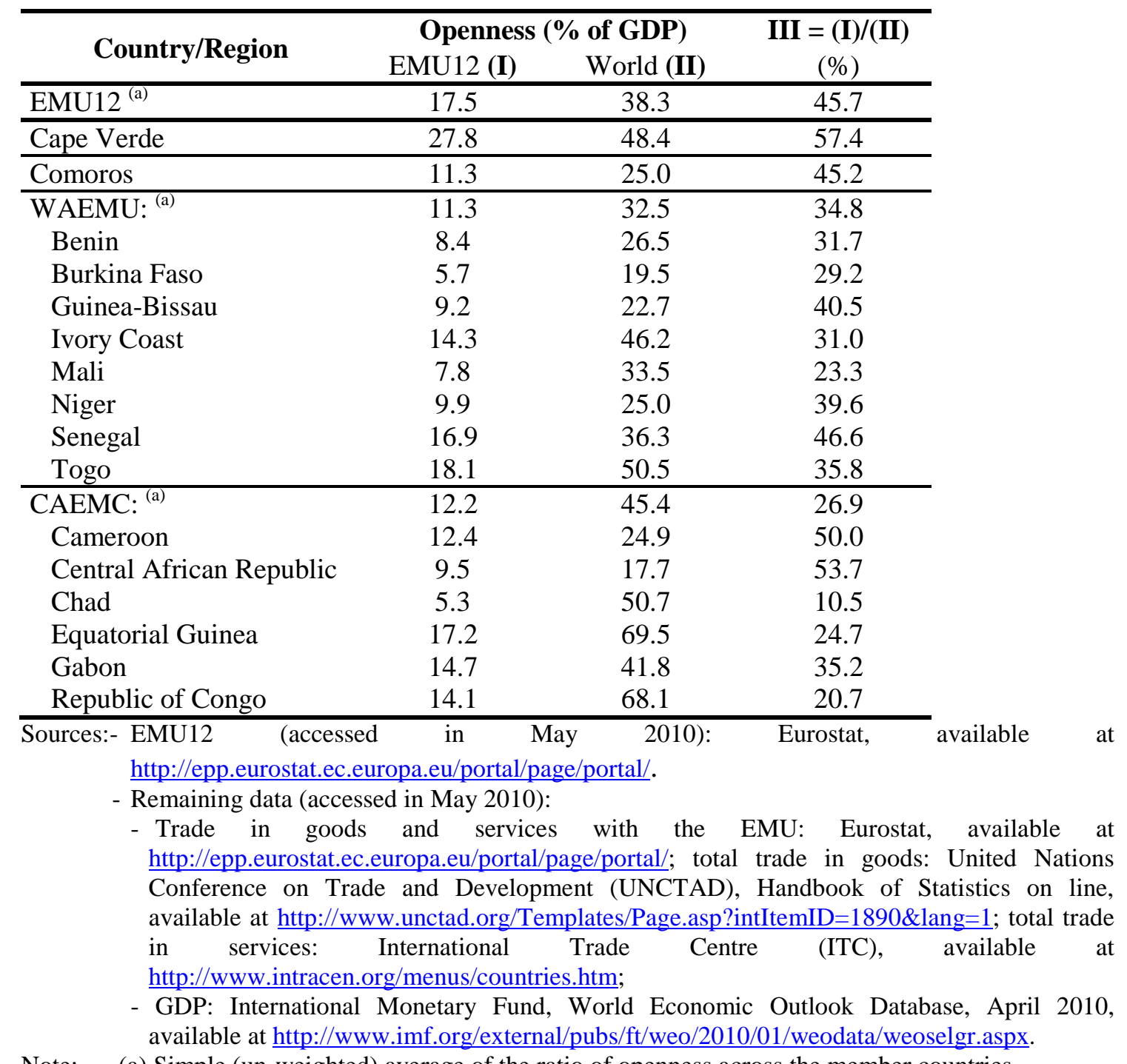

Note: (a) Simple (un-weighted) average of the ratio of openness across the member countries.

In comparison to the EMU12 (which featured a total degree of openness of $38.3 \%$ of GDP), seven countries under analysis are more open. They are Cape Verde (48.4\%), Ivory Coast (46.2\%), Togo (50.5\%), Chad (50.7\%), Equatorial Guinea (69.5\%), Gabon $(41.8 \%)$ and the Republic of Congo (68.1\%). However, out of these seven countries, only two have a degree of trade with EMU12 that is higher than the average of EMU12 internal trade $(17.5 \%)$. They are Cape Verde $(27.8 \%)$ and Togo $(18.1 \%)$.

In seven countries (Benin, Burkina Faso, Guinea-Bissau, Mali, Niger, Central African Republic, and Chad) the average of exports to and imports from EMU12 represents less 
than $10 \%$ of the respective GDP. ${ }^{13}$ From the last column, one can see that there are three countries (Cape Verde, Cameroon, and the Central African Republic) whose trade with the EMU12 represents at least $50 \%$ of their total trade. However, out of this group only Cape Verde has a high degree of total openness.

With the exception of Cape Verde, the general picture that emerges from Table 2 is that the African countries that have been anchored to the euro do not show particularly high trade intensities with the Euro Area. Accordingly, the trade benefits obtained from having their exchange rates fixed are hardly high.

Moreover, in some countries exports are concentrated in a limited number of commodities. Since commodities are traditionally priced in dollars, those exports do not benefit from exchange rate stability against the euro, even when the exports are to Euro Area countries. This point is made clear in Table 3, where we provide information on the shares of exports of different goods in total exports of each country. We have selected the most representative goods and services and, among them, we have identified those considered as commodities (shadowed lines in Table 3) based on the classification presented in the Indices of Primary Commodity Prices, 1999-2010, published by the $\mathrm{IMF}^{14}$. The figures reported are averages for the most recent five years with available data (typically 2004-08).

\footnotetext{
${ }^{13}$ It is likely that figures for coastal countries are overestimated while figures for landlocked countries are underestimated. The reason is that some imports by landlocked countries are actually re-exports by coastal countries.

${ }^{14}$ Available at http://www.imf.org/external/np/res/commod/table1a.pdf.
} 
Table 3. Export structure by main type of product as a share of total exports (\%), average of most recent 5 years

\begin{tabular}{|c|c|c|c|c|c|c|c|c|c|c|c|c|c|c|c|c|c|}
\hline \multirow[b]{2}{*}{$\begin{array}{c}\text { HS (goods) \& } \\
\text { BPM (services) } \\
\text { Codes }\end{array}$} & \multirow[b]{2}{*}{ Product/Country } & \multirow[b]{2}{*}{ U⿺辶寸 } & \multirow[b]{2}{*}{$\begin{array}{l}0 \\
0 \\
0 \\
0\end{array}$} & \multicolumn{8}{|c|}{ WAEMU } & \multicolumn{6}{|c|}{ CAEMC } \\
\hline & & & & 志 & 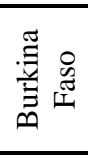 & 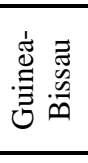 & $\begin{array}{l}\overrightarrow{0} \\
0 \\
0 \\
0 \\
0 \\
0\end{array}$ & $\overline{\bar{\Sigma}}$ & $\begin{array}{l}\overrightarrow{D_{0}} \\
\stackrel{.00}{Z}\end{array}$ & 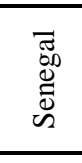 & $\begin{array}{l}0 \\
80 \\
0 \\
0\end{array}$ & 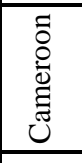 & 焉芯芯 & تี & 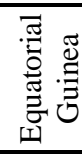 & రే & 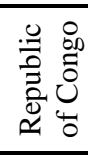 \\
\hline 01 & Live animals & & & & & & & & 8.8 & & & & & & & & \\
\hline 03 & Fish, crustaceans, molluscs, aquatic invertebrates nes & 2.6 & & & & & & & & 12.2 & & & & & & & \\
\hline 07 & Edible vegetables and certain roots and tubers & & & & & & & & 6.1 & & & & & & & & \\
\hline 08 & Edible fruit, nuts, peel of citrus fruit, melons & & & 3.9 & & 82.9 & & & & & & & & & & & \\
\hline 09 & Coffee, tea, mate and spices & & 15.8 & & & & & & & & & & & & & & \\
\hline 12 & Oil seed, oleagic fruits, grain, seed, fruit, etc, nes & & & & 4.8 & & & & & & & & & & & & \\
\hline 18 & Cocoa and cocoa preparations & & & & & & 25.5 & & & & 7.9 & 6.2 & & & & & \\
\hline 24 & Tobacco and manufactured tobacco substitutes & & & 3.8 & & & & & & & & & & & & & \\
\hline 25 & Salt, sulphur, earth, stone, plaster, lime and cement & & & & & & & & & 3.7 & 20.5 & & & & & & \\
\hline 26 & Ores, slag and ash & & & & & & & & 36.3 & & & & & & & 8.3 & \\
\hline 27 & Mineral fuels, oils, distillation products, etc & 6.6 & & 3.6 & & & 28.0 & & & 13.8 & & 41.9 & & 91.0 & 94.7 & 75.1 & 85.2 \\
\hline 28 & Inorganic chemicals, precious metal compound, isotopes & & & & & & & & & 6.4 & & & & & & & \\
\hline 33 & Essential oils, perfumes, cosmetics, toileteries & & 4.7 & & & & & & & & & & & & & & \\
\hline 44 & Wood and articles of wood, wood charcoal & & & & & & & & & & & 12.5 & 32.5 & & & 11.6 & \\
\hline 52 & Cotton & & & 30.5 & 63.1 & & & 19.5 & & & 23.0 & & 6.2 & & & & \\
\hline 59 & Impregnated, coated or laminated textile fabric & & & 5.3 & & & & & & & & & & & & & \\
\hline 62 & Articles of apparel, accessories, not knit or crochet & 0.9 & & & & & & & & & & & & & & & \\
\hline 64 & Footwear, gaiters and the like, parts thereof & 0.8 & & & & & & & & & & & & & & & \\
\hline 71 & Pearls, precious stones, metals, coins, etc & & & & & & & 53.0 & 7.7 & & & & 22.2 & & & & \\
\hline 72 & Iron and steel & & & & & & & & & & 4.6 & & & & & & \\
\hline 86 & Railway, tramway locomotives, rolling stock, equipment & 1.9 & & & & & & & & & & & & & & & \\
\hline 87 & Vehicles other than railway, tramway & & & & & & 6.0 & & & & & & & & & & \\
\hline 89 & Ships, boats and other floating structures & & 10.6 & & & & & & & & & & & & & & \\
\hline 90 & Optical, photo, technical, medical, etc apparatus & & 3.5 & & & & & & & & & & & & & & \\
\hline 99 & Commodities not elsewhere specified & & 9.8 & & & & & & & & & & & & & & \\
\hline 200 & Services & 83.6 & 52.2 & 38.1 & 14.5 & 9.6 & 9.9 & 19.1 & 18.3 & 36.4 & 25.6 & 24.4 & 28.7 & 3.8 & 0.5 & 2.5 & 3.2 \\
\hline \multicolumn{2}{|c|}{ Goods (representing at least $5 \%$ of total exports of goods) and services as $\%$ of total exports } & 96.4 & 96.6 & 85.2 & 82.4 & 92.5 & 69.5 & 91.6 & 77.3 & 72.5 & 81.8 & 85.0 & 89.7 & 94.8 & 95.1 & 97.4 & 88.4 \\
\hline & of which commodities & 9.2 & 15.8 & 38.0 & 67.9 & 82.9 & 53.6 & 19.5 & 42.5 & 26.1 & 31.0 & 60.6 & 38.8 & 91.0 & 94.7 & 95.0 & 85.2 \\
\hline
\end{tabular}

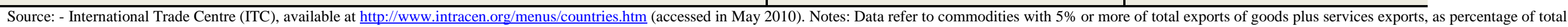

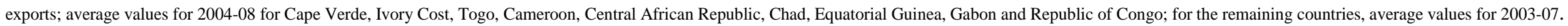


As can be seen in Table 3, Cape Verde is the country that has had the highest degree of integration with the Euro Area and that has the lowest share of commodities in its exports (only 9.2\%). This suggests that Cape Verde may have been able to reap the trade benefits of the peg to the euro. On the other extreme, most countries either have a very small integration with the Euro Area (see Table 2) or a very high share of commodities in their exports (as shown in Table 3). Note that, on average, commodities represent $45.2 \%$ and $77.5 \%$ of total exports, for WAEMU and CAEMC, respectively.

Another perspective to look at trade data is the origin and destination of goods and services. Since all the sixteen countries have been colonies of a European country, it would not be surprising that trade with the former colonizer - and thus with Europe had a large share in their international trade flows. However, the relative importance of such bilateral trade seems to be decreasing, at least for the fourteen WAEMU and CAEMC countries, as suggested by Figure 1 and Figure 2. These figures display, respectively, historical data on exports to and imports from the Euro Area by the set of WAEMU countries and the set of CAEMC countries. Prior to 1999, there was already a decreasing trend in the share of trade with the Euro Area countries. From 1999 onwards, and in spite of the substantial widening of the economic area to which the WAEMU and CAEMC currencies became pegged, the relative importance of trade with the Euro Area kept decreasing. The persistence of such decreasing trend, together with the relatively high weight of commodities in the exports of many of these countries, casts serious doubts on the benefits of the peg to the euro, as far as trade is concerned. ${ }^{15}$

\footnotetext{
${ }^{15}$ The peg to the euro, the appreciation of the euro against the dollar in the first years of the current century, plus the decreasing weight of trade with the Euro Area have very likely changed the real effective exchange rate of the CFA franc zone. According to Hallet (2008), between 2000 and 2006, there was a real effective appreciation of $14 \%$.
} 
Figure 1. WAEMU and CAEMC exports to the Euro Area, 1989-2008

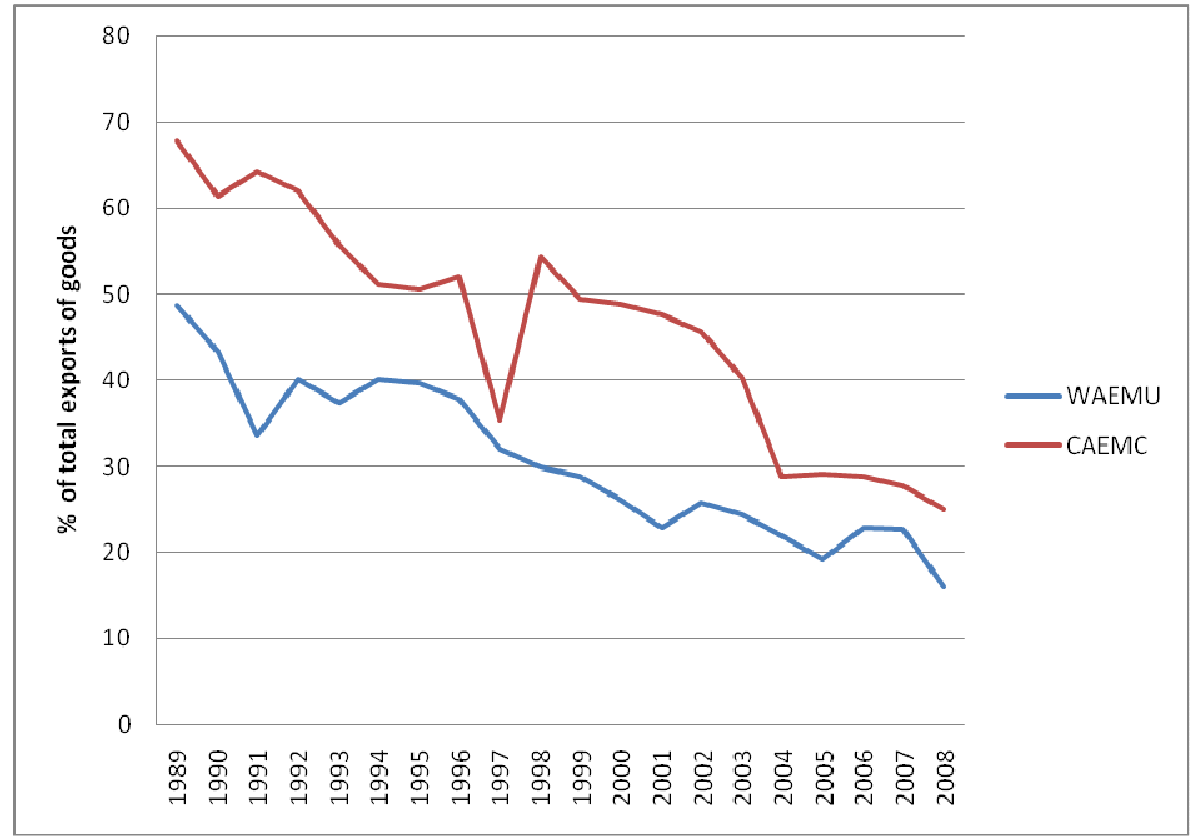

Source: - United Nations Conference on Trade and Development (UNCTAD) - Handbook of Statistics on line, available at http://www.unctad.org/Templates/Page.asp?intItemID=1890\&lang=1 (accessed in May 2010).

\section{Figure 2. WAEMU and CAEMC imports from the Euro Area, 1989-2008}

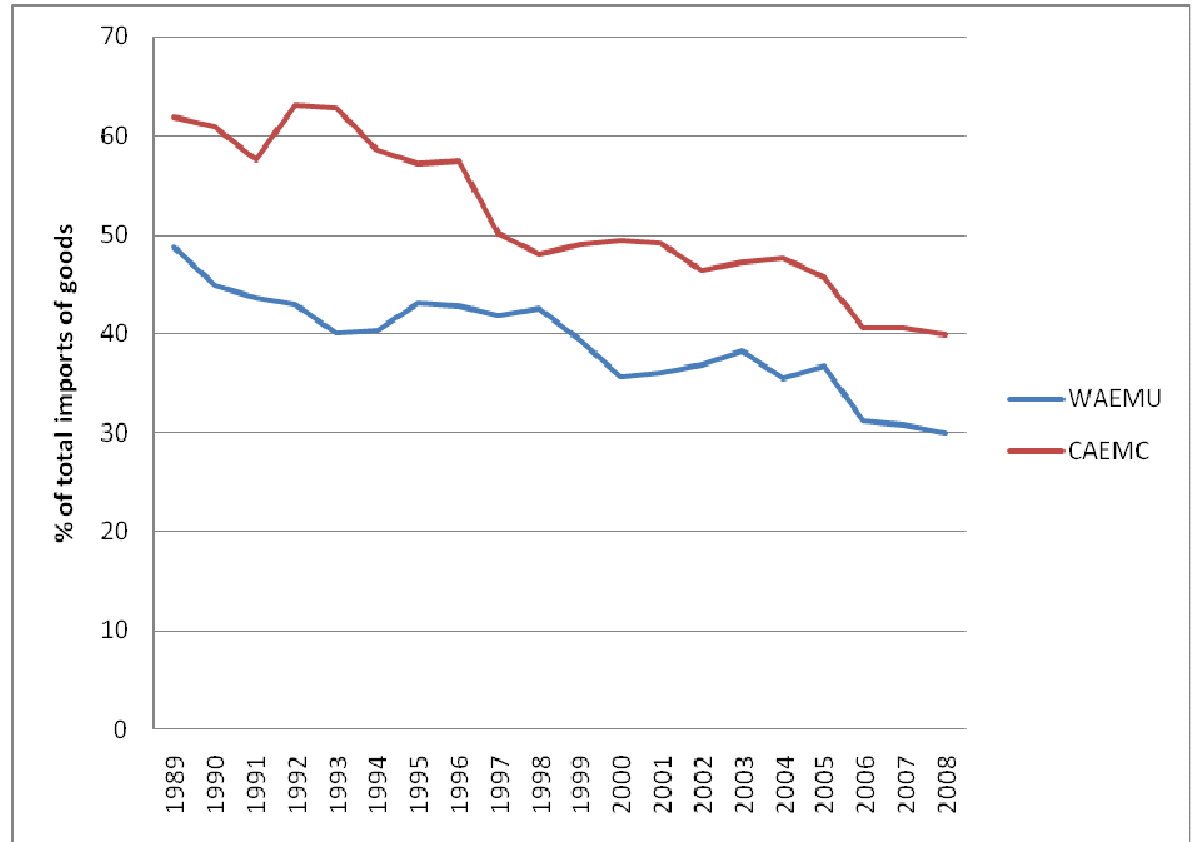

Source: - United Nations Conference on Trade and Development (UNCTAD) - Handbook of Statistics on line, available at http://www.unctad.org/Templates/Page.asp?intItemID=1890\&lang=1 (accessed in May 2010). 


\section{Synchronization of business cycles}

We gauge synchronization using the linear correlation coefficient between the output gap of each country $\left(g_{i}\right)$ and the gap of the Euro Area $\left(g_{E M U}\right)$ :

$$
\rho\left(g_{i}, g_{E M U}\right)=\frac{\operatorname{Cov}\left(g_{i}, g_{E M U}\right)}{\sigma\left(g_{i}\right) \sigma\left(g_{E M U}\right)}=\frac{\sum_{t}\left(g_{i(t)}-\bar{g}_{i}\right)\left(g_{E M U(t)}-\bar{g}_{E M U}\right)}{\sqrt{\sum_{t}\left(g_{i(t)}-\bar{g}_{i}\right)^{2}\left(g_{E M U(t)}-\bar{g}_{E M U}\right)^{2}}}
$$

where $\bar{g}_{i}$ and $\bar{g}_{E M U}$ are the corresponding average output gaps for the sample period (which are essentially zero, by construction). In spite of its simplicity, correlation coefficients have been extensively used in recent studies of business cycle synchronization, irrespectively of the approach used to measure the cycle - see De Haan, Inklaar and Jong-A-Pin (2008) for a survey. ${ }^{16}$

For the period 1999-2008, Table 4 provides the results for business cycle synchronization between each country under analysis and the Euro Area. As a reference, in the first line of the table we also report the degree of business cycle synchronization within the Euro Area, measured as the simple average of the correlation coefficients of each EMU12 member output gap with the gap of the aggregate EMU12 (obtained with the same method and for the same period as for the African countries).

The output gaps have been computed from annual time series of real GDP from 1980 to 2008. ${ }^{17}$ Although higher frequency data would be more adequate for studying exchange rate and monetary policies, there are no available or reliable quarterly real GDP data for the African countries in our sample period. While quarterly data for industrial production indexes has been used elsewhere in the literature (e.g. Rand and Tarp, 2002) we do not find such approach particularly useful, in view of the large weight of agriculture and commodities in the GDP of most of the countries. We also choose not to

\footnotetext{
${ }^{16}$ Many studies go beyond simple contemporary correlations and (i) compare correlations for different sample periods (or look at rolling correlations) or (ii) compute non-contemporaneous correlations. Given our purposes and the small dimension of our sample, we merely compute the correlations for the whole euro-peg period (1999-2008). We also chose not to look at non-contemporaneous correlations as they would only be relevant for assessing the adequacy of a single monetary policy if the data had higher frequency.

${ }^{17}$ The data source for the African countries is the World Economic Outlook database of the International Monetary Fund (IMF), while Euro Area data have been obtained from AMECO. See: World Economic Outlook Database of the IMF, version April 2010, available at https://www.imf.org/external/pubs/ft/weo/2010/01/weodata/index.aspx, and AMECO database, available at http://ec.europa.eu/economy_finance/db indicators/ameco/index_en.htm.
} 
follow the artificial alternative of implementing a merely statistical interpolation of annual GDP data (e.g. Shortland and Stasavage, 2004). ${ }^{18}$

Output gaps were obtained by filtering the log of real GDP with the Hodrick-Prescott (HP) filter (Hodrick and Prescott, 1997). The smoothing parameter $\lambda$ was set at 6.25 , the value that mimics with annual data the results obtained with the HP filter on quarterly data (Ravn and Uhlig, 2002). ${ }^{19}$

The econometric framework adopted here corresponds to a deviation cycle approach to the measurement of the business cycle (for a comparison with the alternative classical and growth cycle approaches, see Artis, Marcellino and Proietti, 2004). The specific choice of the HP filter, rather than alternative procedures requiring estimation, is due to the scarcity of data resulting from its periodicity and the purpose of focusing the analysis only on the period of the peg to the euro. ${ }^{20}$

As Table 4 shows, out of the sixteen African countries pegged to the euro, only two have business cycles that may be considered significantly synchronized (at standard levels of significance) with that of the Euro Area. They are the Central African Republic

\footnotetext{
${ }^{18}$ Some studies use per capita real GDP, rather than real GDP. We argue that per capita GDP would be suitable if (i) the period under analysis was considerably larger, (ii) the reliability of population statistics was more satisfactory and (iii) the empirical assessment would not involve a proper extraction of the cyclical component of the original time-series. Still, as a sensitivity check, we have computed the output gaps and their correlation to the EMU12 cycle, using per capita real GDP data. The results (available upon request) are qualitatively similar to those herein presented.

${ }^{19}$ The resulting output gaps, as well as all data used in this paper, are available from the authors upon request.

${ }^{20}$ We are well aware of yet other alternative approaches to the measurement of co-movements of real output, often used in the literature of optimal currency areas, which compute the correlation between output shocks. As surveyed by Tavlas (2009), this approach has in fact two main bodies of literature. First, a number of studies follows Alesina, Barro and Tenreyro (2002) and computes the co-movement between output shocks estimated from auto-regressive processes for (the $\log$ of) relative real outputs. Second, several studies compute the co-movements between demand and supply shocks estimated from structural VARs identified along the lines of Blanchard and Quah (1989). Bayoumi and Ostry (1997, page 428) argue that the identification of supply and demand shocks may not be successfully implemented in the African context, as in Africa most of the supply shocks are temporary and would thus be identified as demand shocks with the Blanchard-Quah approach; they consequently use an approach in the spirit of Alesina, Barro and Tenreyro (2002). Because we focus on a period of merely 10 years, with annual data, we are unable to follow any of these econometric approaches, as well as alternative methods for the extraction of deviation cycles requiring estimation rather than calibration.
} 
and Cape Verde, with correlation coefficients of 80 percent and 74 percent, respectively. ${ }^{21,22}$ Moreover, the synchronization of business cycles of these two countries with the Euro Area is not markedly lower than the synchronization recorded by the individual members of EMU12 (they display a simple mean of 82 percent). We do not find any geographic rationale for the results of these two countries since the Central African Republic and Cape Verde are not neighbors and do not belong to the same regional African monetary union (Cape Verde is an archipelago and does not belong to the CFA arrangement, while the Central African Republic is a landlocked country belonging to the CAEMC).

Among the remaining fourteen countries, there are nine cases of negative correlations (statistically significant in the case of Niger) and those that are positive are not statistically significant. The lack of business cycle synchronization for most of the countries suggests that the peg to the euro represents actually a cost for many of them, in the sense that they are subject to monetary policies that do not fit the needs of their observed output fluctuations. Thus, on the basis of this economic criterion, the euro does not seem an adequate anchor for most of the African countries that have had their currencies pegged to the European currency.

\footnotetext{
${ }^{21}$ As is well known, under the null hypothesis that the true correlation between $\mathrm{X}$ and $\mathrm{Y}$ is $\rho=0$, if the sample in which the observed correlation $r$ is computed is not smaller than $\mathrm{N}=6$, then the test statistic $t=\frac{r}{\sqrt{\left(1-r^{2}\right) /(N-2)}}$ is approximately distributed as a Student- $\mathrm{t}$ with degrees of freedom $\mathrm{df}=\mathrm{N}-2$. In this paper, given the sample size $\mathrm{N}=10$, correlation coefficients equal or larger than 0.55 may be considered statistically different from 0 at the usual 5 percent level of significance.

${ }^{22}$ The high correlations found for Cape Verde and the Central African Republic still hold when the sample is successively extended backwards to include additional years through 1993-2008.
} 
Table 4. Correlation coefficients with the Euro Area business cycle, 1999-2008

\begin{tabular}{lc}
\hline \multicolumn{1}{c}{ Country/Region } & Correlation coefficient \\
\hline EMU12 ${ }^{\text {(a) }}$ & $\mathbf{0 . 8 1 6}$ \\
\hline Cape Verde & $\mathbf{0 . 7 4 1}$ \\
\hline Comoros & -0.473 \\
\hline WAEMU: & \\
Benin & 0.005 \\
Burkina Faso & -0.325 \\
Guinea-Bissau & 0.304 \\
Ivory Coast & -0.025 \\
Mali & -0.504 \\
Niger & -0.556 \\
Senegal & 0.133 \\
Togo & -0.185 \\
\hline CAEMC: & \\
Cameroon & 0.066 \\
Central African Republic & $\mathbf{0 . 7 9 6}$ \\
Chad & -0.468 \\
Equatorial Guinea & -0.221 \\
Gabon & -0.493 \\
Republic of Congo & 0.187 \\
\hline
\end{tabular}

Source: Authors' calculations.

Notes: (a) Simple (un-weighted) average of the correlations of the member countries.

Values in bold are positive and statistically different from 0 at the 5 percent level of significance.

One obvious explanation for the low synchronization of business cycles found for many countries relative to the Euro Area is the concentration of production and exports in a limited number of commodities, as mentioned above. Such a feature leads to idiosyncratic shocks related with swings in world prices, and the corresponding changes in terms of trade, as well as shocks related with the impact of climate conditions on crops (see, e.g., Hoffmaister, Roldós and Wickham, 1998, Kose and Riezman, 2001, and Van den Boogaerde and Tsangarides, 2005). ${ }^{23}$ The sensitivity of the African countries to supply shocks is apparent in the fact that the variability of their output gaps is, overall, quite larger than the variability of the EMU12 countries' output gaps. ${ }^{24}$

\footnotetext{
${ }^{23}$ Houssa (2008) provides a description of the events behind demand and supply shocks of the members of ECOWAS (Economic Community of West African States). Most of those countries are part of our sample.

${ }^{24}$ For the sake of space conservation, figures for the volatility of the output gaps are not reported. We note, however, that the high correlations of the Central African Republic and Cape Verde in Table 4 are particularly noteworthy, given that the standard deviations of both countries' output gaps are quite larger than that of the Euro Area (0.024 and 0.016, respectively, which compare with 0.007 for the Euro Area). The only countries with a cyclical volatility not higher than the Euro Area's are Benin, Cameroon and Comoros, but their output gaps do not correlate positively with the Euro Area output gap.
} 


\section{Trade integration and cyclical synchronization: a joint assessment}

Following Frankel (1999), we provide in Figure 3 a joint assessment of criteria (i) and (iii). The figure jointly displays the correlations from Table 4 and the degree of trade integration from the first column of Table 2 (trade with the Euro Area as percentage of domestic GDP). As an ad hoc reference for judging the adequacy of the peg, we use the integration-synchronization record of the EMU12 countries.

In addition to the position of each African country in the integration-synchronization nexus and the position of the average of the EMU12 countries, our figure includes a vertical and a horizontal orientation lines that cross the EMU12 locus. These lines define four quadrants in the diagram: the first quadrant identifies the countries that perform better than the average EMU12 members in both indicators; the third quadrant identifies countries that fare worse in both criteria; in the second and fourth quadrants lay the countries that fare better in one and worse in the other indicator. The EMU12 average is represented as a triangle, Cape Verde and Comoros as diamonds, the WAEMU members as squares and the CAEMC members as circles.

Figure 3. Cyclical correlation and trade integration with EMU12

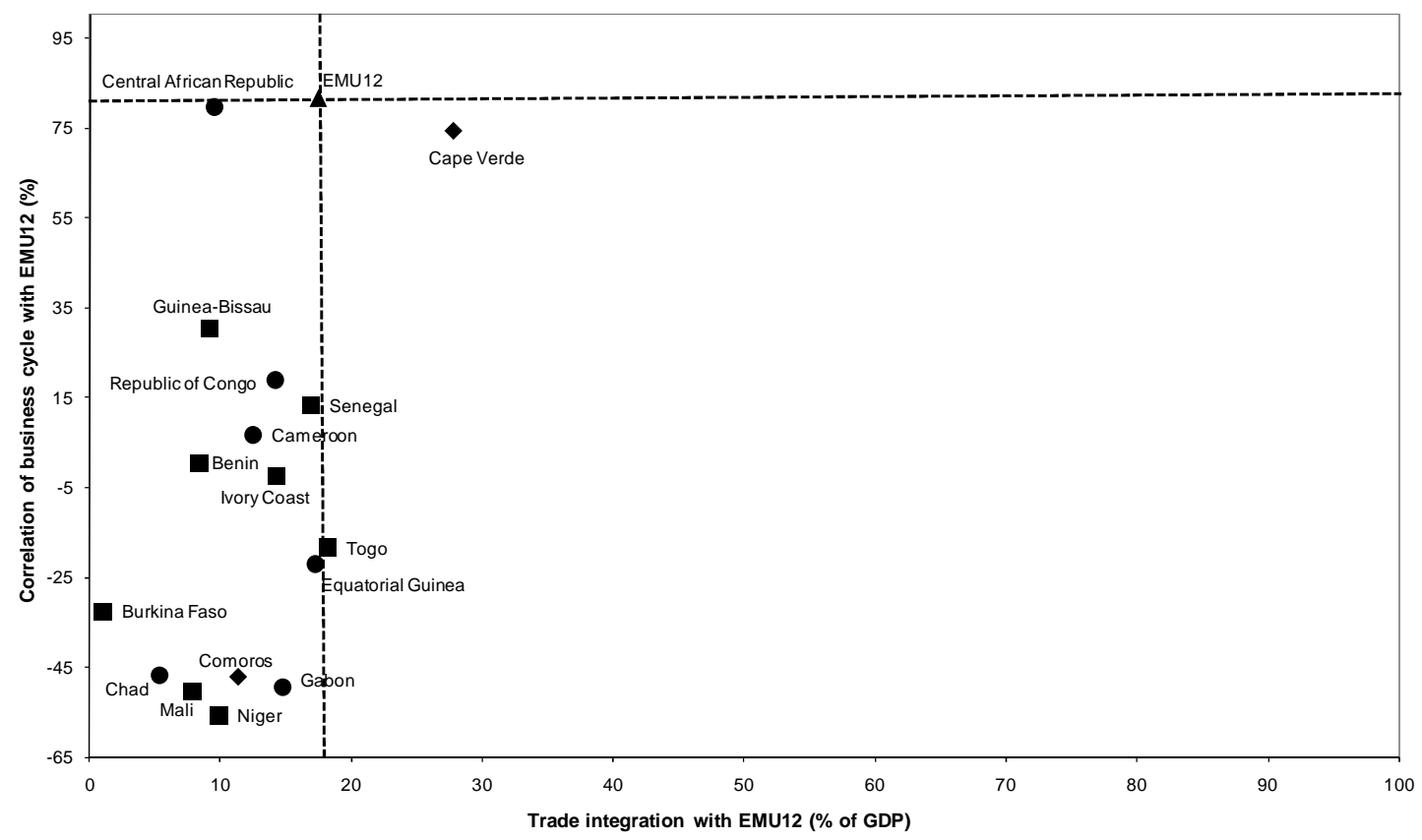


The figure clearly shows that the Central African Republic and Cape Verde are the only countries in the sample that are close to the EMU12 benchmark. Note that Cape Verde has a remarkable performance concerning trade with the Euro Area, being even quite more integrated than the average of the EMU12 countries. The high trade integration of Cape Verde helps in explaining its high synchronization of business cycles. This is a clear case of a country that has adopted the right anchor to peg. In the case of the Central African Republic, the high correlation of business cycles with EMU12 is harder to explain, given the relatively low level of trade integration with the Euro Area.

The remaining countries are all located in the third quadrant at a relatively (and unfavorable) high distance from the reference point. In general, for these countries, our findings do not support their current exchange rate regime.

Given our conclusion that the euro, according to our criteria, is not an appropriate anchor for most of the countries under analysis, we have replicated the exercise for the most obvious alternative, the US dollar. The results found for the degree of openness and correlation of business cycles of the 16 countries relative to the US are reported in the Annex. The main conclusion that can be drawn from those results is that for Cape Verde the euro is clearly an adequate anchor while for the remaining countries neither the euro nor the dollar are superior alternatives relative to each other. Some CAEMC countries are clearly more open relative to the US than to the Euro Area (Chad and Congo) and 3 countries in the sample have business cycles clearly better synchronized with the US than with the Euro Area (Burkina Faso, Senegal and Togo). On the whole, our findings raise two issues, namely: (i) instead of pegging to a single currency, would not be more appropriate for most of the countries to adopt a peg against a basket of currencies? (ii) Given the diversity of performances, is it appropriate for all the countries in the sample to have a common anchor? This latter question can be translated into another one: are the CAEMC and the WAEMU appropriate groupings of countries? Answering the first issue involves finding for each country the right basket of currencies for anchoring, a task which is beyond the scope of this paper. The second issue is analyzed in what follows. 


\section{The CFA franc monetary unions: are they optimal?}

Adding to previous findings in the literature, we have presented evidence that the fixed exchange rate regime has been an appropriate strategy for keeping inflation under control in Cape Verde, Comoros and in the fourteen CFA countries. However, for most of them, a deeper analysis led us to conclude that the euro has not been the right currency for anchoring.

Truly, for the fourteen CFA countries, the peg to the euro was not an individual decision but a collective one, taken for the whole monetary union to which they belong. And we cannot disregard that the gathering of countries in the WEAMU and CAEMC is the continuation of an administrative division from the French colonial era, hardly based on OCA requirements. The purpose of this section is just to assess whether there is economic support for the grouping of the CFA countries in the two existing monetary unions.

As in section 2, we carry out the assessment for 1999-2008, on the basis of Alesina and Barro's criteria, and using the corresponding historical records for the EMU12 as benchmark. Since we have already seen that low inflation is common to the sixteen African countries, we limit the analysis to intra-union trade and to the synchronization of business cycles within each monetary union - criteria (i) and (iii).

For a period previous to the euro-peg, Bayoumi and Ostry (1997) have conducted an exercise similar to ours and found that neither the WAEMU nor the CAEMC were optimal monetary unions. This section will allow for checking whether such a conclusion still applies with more recent data. ${ }^{25}$

\footnotetext{
${ }^{25}$ The only technical difference between our empirical strategy and Bayoumi and Ostry's (1997) occurs in the study of business cycle synchronization. To compute the correlations we use output gaps while they use the residuals of autoregressive models of the log change of real GDP. This technical alternative is discarded due to our limited number of observations.
} 


\section{Trade integration}

For the period 2003-2008, Table 5 reports the relative importance of international trade in goods of each WAEMU and CAEMC country with the remaining members of the respective monetary union. Column I provides intra-union trade of each country relative to GDP, column II provides total trade relative to GDP, and column III represents the intra-union trade of each country relative to its total international trade. For each of these three indicators, the table also reports the global figure for each monetary union, which is the sample mean of their members. As an ad-hoc benchmark, we also provide, for the three indicators, the simple mean of the EMU12 countries.

The relative importance of total trade is similar in both monetary unions. In WAEMU total trade represents, on average, $26.2 \%$ of the corresponding GDP, while in CAEMC it represents $34.4 \%$. However, in the case of CAEMC, internal trade is almost nonexisting, since it represents only $0.6 \%$ of GDP and $1.7 \%$ of total trade. In the case of the WAEMU, the figures are slightly higher: intra-union trade represents, on average, $3.6 \%$ of GDP and $13.7 \%$ of total trade. ${ }^{26}$ Compared to the Euro Area, internal trade in CFA monetary unions is very low. In fact, on average, intra-EMU12 trade represents $15.5 \%$ of the corresponding GDP and about one half of total trade.

The very low levels of intra-union trade, both in WAEMU and CAEMC, can be explained on different grounds. Regarding exports, the main explanation in that for many countries production is confined to a small number of primary commodities that are inputs essentially used by industrial countries. As regards imports, most are investment and consumer goods that are not produced by the neighbor African countries - belonging to the monetary union - but rather by developed countries. Civil unrest and poor infrastructures, namely poor transportation and communications networks, are also relevant factors hampering intra-union trade (see, inter alia, Longo and Sekkat, 2004).

\footnotetext{
${ }^{26}$ Concerning the figures reported in Table 5, two notes are in order: (i) Official statistics for intra-trade of WAEMU and CAEMC are very likely under-reporting actual trade due to informal transactions carried between neighboring regions of different countries. In any case, there is a consensus that even if figures for actual trade were available, intra-union trade would still represent a small proportion of international trade of WAEMU and CAEMC. (ii) Part of the trade counted as intra-union (particularly in the case of WAEMU) is actually trade between coastal and landlocked countries of goods in transit.
} 
Table 5. International trade in goods, 2003-08

\begin{tabular}{lccc}
\hline \multirow{2}{*}{ Country/Region } & \multicolumn{2}{c}{ Openness (\% of GDP) } & III=(I)/(II) \\
& Intra-union (I) & World (II) & $(\%)$ \\
\hline EMU12 $^{(a)}$ & 15.5 & 31.2 & 49.7 \\
WAEMU $^{(a)}$ & 3.6 & 26.2 & 13.7 \\
Benin & 2.3 & 20.5 & 11.2 \\
Burkina Faso & 3.7 & 16.0 & 23.1 \\
Guinea-Bissau & 4.8 & 19.3 & 24.9 \\
Ivory Coast & 2.5 & 38.1 & 6.6 \\
Mali & 4.4 & 26.0 & 16.9 \\
Niger & 1.8 & 20.4 & 8.8 \\
Senegal & 2.7 & 27.2 & 9.9 \\
Togo & 6.8 & 41.9 & 16.2 \\
\hline CAEMC ${ }^{\text {(a) }}$ & 0.6 & 34.4 & 1.7 \\
Cameroon & 0.6 & 17.3 & 3.5 \\
Central African Republic & 1.1 & 11.7 & 9.4 \\
Chad & 0.8 & 35.0 & 2.3 \\
Equatorial Guinea & 0.0 & 55.9 & 0.0 \\
Gabon & 0.6 & 35.2 & 1.7 \\
Republic of Congo & 0.4 & 51.1 & 0.8 \\
\hline
\end{tabular}

Sources: - EMU12: Eurostat, (accessed in June 2010) available at

http://epp.eurostat.ec.europa.eu/portal/page/portal/external trade/data/database and at http://epp.eurostat.ec.europa.eu/portal/page/portal/national_accounts/data/database

- Remaining data (accessed in June 2010):

- Trade: United Nations Conference on Trade and Development (UNCTAD) - Handbook of Statistics, available at http://www.unctad.org/Templates/Page.asp?intItemID=1890\&lang=1.

- GDP: International Monetary Fund, World Economic Outlook database, April 2010, available at http://www.imf.org/external/pubs/ft/weo/2010/01/weodata/weoselgr.aspx.

Note: (a) Simple (un-weighted) average of the ratio of openness across the member countries.

Overall, the information provided makes clear that one of the main benefits from sharing a common currency does not hold in the case of the two CFA monetary unions. In fact, intra-trade is supposed to be boosted through the vanishing of both foreign exchange transactions costs and exchange rate risk. ${ }^{27}$ However, for the reasons just mentioned, it is not surprising that other structural factors may out-weight the potential trade benefits resulting from a single currency. Accordingly, great emphasis should not be put on intra-trade as a criterion for deciding the adequacy of an African monetary union.

\footnotetext{
${ }^{27}$ The low figures for intra-trade in CFA monetary unions seem to go against empirical findings that currency unions have a large positive effect on international trade (see, e.g., Rose, 2000). However, Carrère (2004) and Masson and Pattillo (2004b) note that trade within CFA monetary unions are around three times higher than trade between African countries with own currencies.
} 


\section{Synchronization of business cycles}

Given that trade benefits are not relevant, it must be the case that the costs cannot either be high. Otherwise, participation in a monetary union does not have any economic support. We next check a specific potential cost ensuing from participation in WAEMU and CAEMC, namely the loss of monetary autonomy. The task is carried out by analyzing the synchronization of business cycles within each monetary union.

We start by computing the correlations of bilateral business cycles within WAEMU and CAEMC. The results are reported in Table 6 and may be summarized as follows. Half of the twenty-eight cross-correlations for WAEMU countries are negative, while in the case of the CAEMC there are ten out of fifteen cross-correlations that are negative. None of the five positive correlations recorded in CAEMC is above 0.55 , the critical point for rejection of the null of insignificance at a one-sided 5 percent probability level (assuming normality and taking into account the sample size). ${ }^{28}$ In the WAEMU countries, there are five significantly positive cross-correlations. Specifically, the output gap of Burkina Faso has a positive and significant correlation coefficient with the output gaps of Ivory Coast and Niger. Additionally, we find positive and statistically significant synchronization of business cycles for the pairs Senegal-Togo and MaliNiger.

\footnotetext{
${ }^{28}$ Our results for CAEMC are in line with those reported in a recent paper by Carmignani (2009). On the basis of output gaps, he also finds that the business cycles of CAEMC countries are not synchronized and that some of them display negative correlation coefficients.
} 
Table 6. Correlation coefficients between national business cycles, 1999-2008

\begin{tabular}{|c|c|c|c|c|c|c|c|c|}
\hline \multirow{2}{*}{$\begin{array}{c}\text { Monetary Union } \\
\text { Countries }\end{array}$} & \multicolumn{8}{|c|}{ WAEMU } \\
\hline & Ben & $\mathrm{BFa}$ & Gui & ICo & Mal & Nig & Sen & Tog \\
\hline Ben & & -0.52 & 0.21 & -0.31 & 0.31 & 0.30 & -0.56 & -0.63 \\
\hline $\mathrm{BFa}$ & & & -0.43 & 0.56 & 0.50 & 0.56 & 0.57 & 0.48 \\
\hline Gui & & & & -0.55 & -0.27 & -0.32 & -0.45 & -0.77 \\
\hline ICo & & & & & 0.28 & 0.33 & 0.50 & 0.40 \\
\hline Mal & & & & & & 0.85 & -0.08 & -0.05 \\
\hline $\mathrm{Nig}$ & & & & & & & -0.18 & -0.01 \\
\hline Sen & & & & & & & & $\mathbf{0 . 5 5}$ \\
\hline Monetary Union & \multicolumn{8}{|c|}{ CAEMC } \\
\hline Countries & Cam & CAR & Cha & EqG & Gab & RCo & & \\
\hline Cam & & 0.01 & -0.06 & 0.24 & -0.47 & -0.70 & & \\
\hline CAR & & & -0.54 & -0.07 & -0.46 & 0.19 & & \\
\hline Cha & & & & 0.47 & 0.23 & -0.08 & & \\
\hline $\mathrm{EqG}$ & & & & & -0.14 & -0.28 & & \\
\hline $\mathrm{Gab}$ & & & & & & -0.08 & & \\
\hline
\end{tabular}

Source: Authors' calculations.

Notes: - Ben: Benin; BFa: Burkina Faso; Gui: Guinea-Bissau; ICo: Ivory Cost; Mal: Mali; Nig: Niger; Sen: Senegal; Tog: Togo; Cam: Cameroon; CAR: Central African Republic; Cha: Chad; EqG: Equatorial Guinea; Gab: Gabon; RCo: Republic of Congo;

- Values in bold are positive and statistically different from 0 at the 5 percent level of significance.

We have also computed the correlations between the output gaps of each country and the output gap of the respective monetary union. Since real GDP data for the aggregate WAEMU and CAEMC are not available, we had to choose and implement some aggregation method. Such decision involved (i) deciding between constant or timevarying weights and (ii) choosing the specific loading for each country's real output. As regards the first decision, we used varying weights, specifically the share of each country's nominal GDP in the respective aggregate in each year. Regarding the measure of nominal GDP used to weight each country's real GDP, we have computed two alternative series, for the sake of some sensitivity check. In the first series we considered as weights the share of GDPs evaluated in US dollars at current market exchange rates (usd). In the second series, we considered each country's GDP evaluated at purchase power parity (ppp). Once we have computed the aggregate real GDP of WAEMU and CAEMC, we then computed their output gaps using, as with the individual countries, the Hodrick-Prescott filter with a smoothing parameter of 6.25. Finally, we computed the correlation between the output gaps of each country and the output gaps of the corresponding monetary union. 
In Table 7 we report the results, which are broadly in line with what could be expected from the previous analysis for pairs of countries. Half of the WAEMU members have positive and significant correlations of their business cycles with the aggregate WAEMU cycle, while about a third of the CAEMC countries have positive and significant correlations with the aggregate CAEMC cycle. More specifically, as regards the WAEMU, Burkina Faso, Ivory Cost, Mali, Niger, have their business cycles significantly correlated with the aggregate cycle, while Senegal and Togo have lower but still positive correlations. In contrast, Benin and Guinea-Bissau have negative correlations, clearly implying that the single monetary policy of WAEMU is not appropriate for these two countries. Regarding the CAEMC, Chad and Equatorial Guinea have a significant degree of synchronization with the aggregate cycle, while Cameroon, the Central African Republic and the Republic of Congo correlate negatively and Gabon has a positive but not significant degree of synchronization.

In short, we find much more cyclical heterogeneity among CAEMC countries than among the WAEMU countries, which questions the existence of the former arrangement. Our results are in line with those obtained by Fielding, Lee and Shields (2004), using earlier data and a different technique (namely, identification of supply and demand shocks with structural vector error correction models). Their conclusion is that (page 513) "there is less heterogeneity in the macroeconomic dynamics of the UEMOA (WAEMU) countries than there is among the CEMAC (CAEMC) members, and so the costs of adhering to a single currency are likely to be lower, ceteris paribus".

The main reason for the lack of synchronization of business cycles is essentially the same that determines low synchronization with the Euro Area. Many of the countries under investigation are producers and exporters of a low number of commodities (that often differ from country to country), which is a source of idiosyncratic shocks. 
Table 7. Correlation coefficients with the aggregate business cycle of WAEMU and CAEMC, 1999-2008

\begin{tabular}{|c|c|c|c|c|}
\hline Monetary Union & $\begin{array}{c}\text { WAEMU } \\
\text { usd }\end{array}$ & $\begin{array}{c}\text { WAEMU } \\
\text { ppp } \\
\end{array}$ & $\begin{array}{c}\text { CAEMC } \\
\text { usd }\end{array}$ & $\begin{array}{c}\text { CAEMC } \\
\text { ppp } \\
\end{array}$ \\
\hline \multicolumn{5}{|l|}{ WAEMU } \\
\hline Benin & -0.265 & -0.241 & & \\
\hline Burkina Faso & 0.820 & 0.836 & & \\
\hline Guinea-Bissau & -0.622 & -0.615 & & \\
\hline Ivory Coast & 0.875 & 0.850 & & \\
\hline Mali & 0.612 & 0.651 & & \\
\hline Niger & 0.617 & 0.661 & & \\
\hline Senegal & 0.540 & 0.510 & & \\
\hline Togo & 0.461 & 0.441 & & \\
\hline \multicolumn{5}{|l|}{ CAEMC } \\
\hline Cameroon & & & -0.299 & -0.114 \\
\hline Central African Republic & & & -0.221 & -0.407 \\
\hline Chad & & & 0.809 & 0.860 \\
\hline Equatorial Guinea & & & 0.667 & 0.753 \\
\hline Gabon & & & 0.376 & 0.463 \\
\hline Republic of Congo & & & 0.066 & -0.102 \\
\hline
\end{tabular}

Source: Authors' calculations.

Notes: - The table shows the correlation coefficient between the output gaps of each country (rows) and the output gaps of the respective monetary union (columns);

- Values in bold are positive and statistically different from 0 at the 5 percent level of significance.

It is worth noting in Table 7 that the business cycle correlations within WAEMU and CAEMC are overall robust to the weighting method used in the computation of the union-aggregate real GDP. It should further be noted that the results do not seem to be driven by the dominance of any individual country in the two union-aggregate real GDPs. In the WAEMU, the largest weight is that of Ivory Coast (about 30 percent), followed by Senegal (about 20 percent), which ranks only fifth as regards correlation with the aggregate. In the CAEMC, the largest weights are those of Cameroon (about 30 percent) and Gabon (about 20 percent), but these countries correlate either negatively or not significantly with the aggregate.

\section{Trade integration and cyclical synchronization: a joint assessment}

The results of this section are summarized in Figure 4 and Figure 5 for WAEMU and CAEMC, respectively. The diagrams are similar to that used by Frankel (1999) for judging optimal currency areas, with the vertical axis measuring the correlation of the business cycle of each country with the cycle of the union's aggregate output (weighted 
by GDPs evaluated at usd), and the horizontal axis measuring trade of each country with the remaining partners of the union (as \% of GDP). As a reference point, we plot in each diagram the average figures of intra-union trade and correlation of business cycles for EMU12, as well as two crossing lines defining four quadrants, as in Figure 3.

Figure 4. Cyclical correlation and trade integration in WAEMU

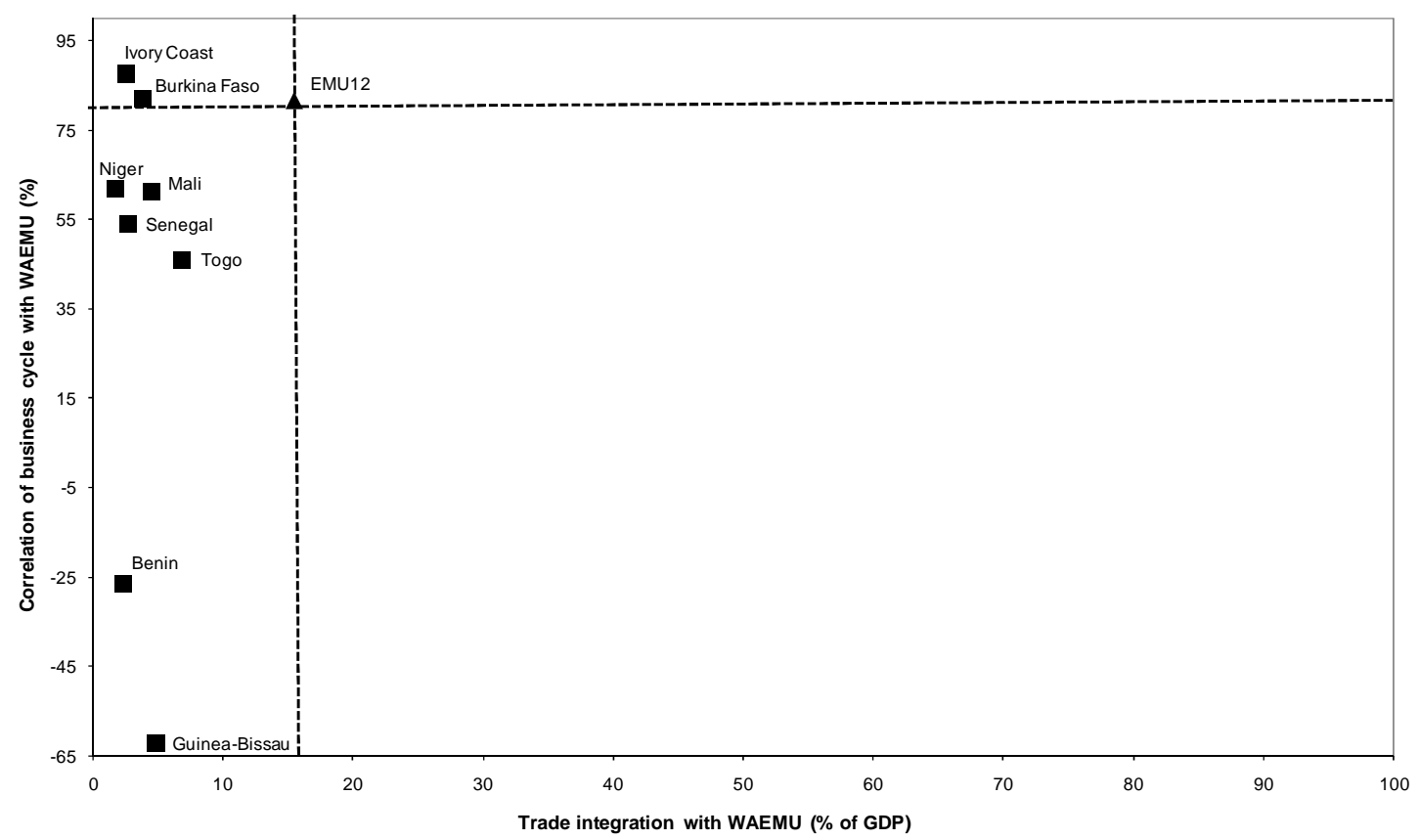


Figure 5. Cyclical correlation and trade integration in CAEMC

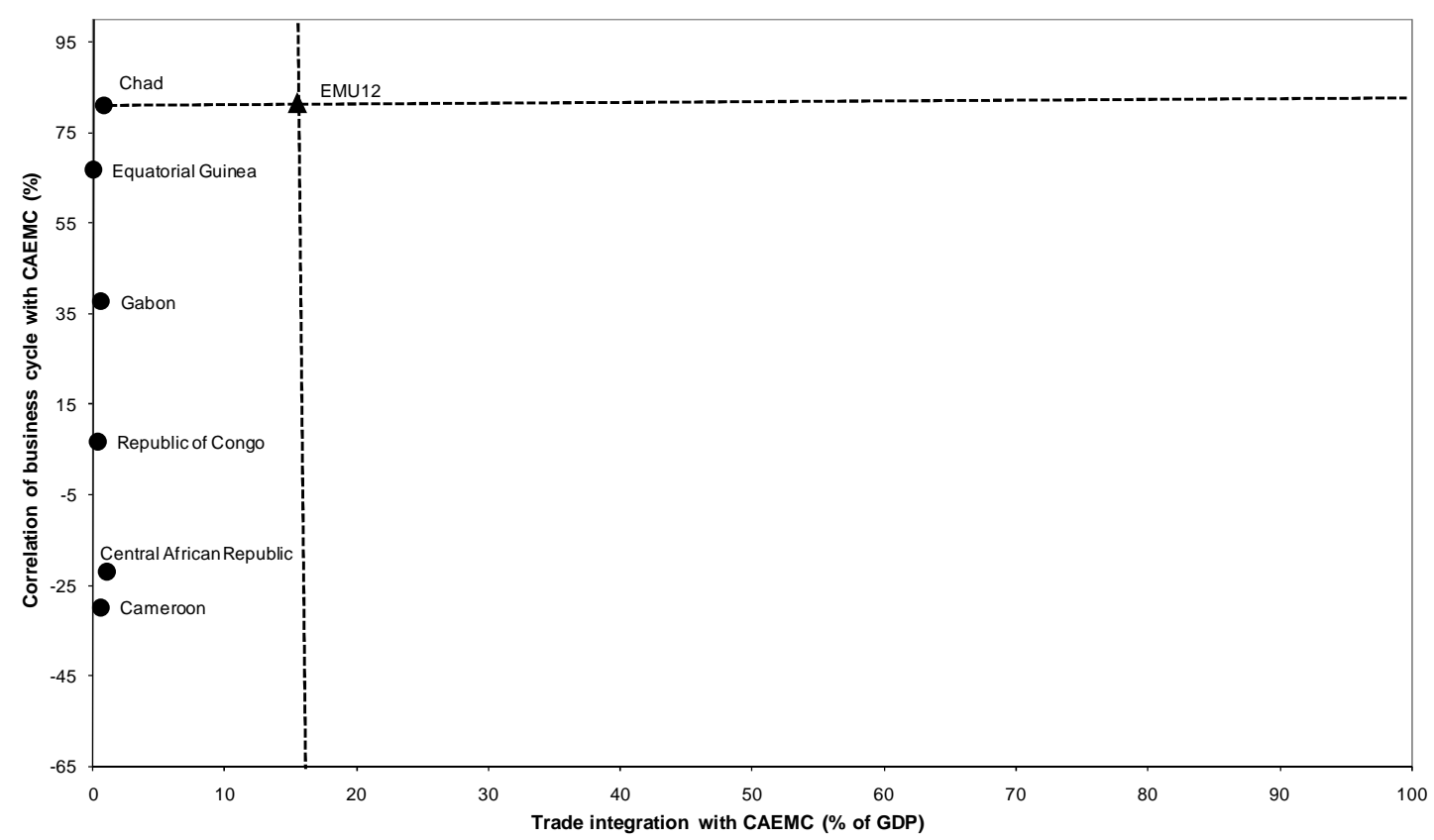

Given the reported low level of intra trade in both CFA monetary unions (more evident in the case of the CAEMC), the only quadrants that become relevant are the third and the fourth. In the case of CAEMC, all the members fall in the third quadrant, with the exception of Chad, which has a correlation of business cycles with the union that is of the same magnitude that, on average, we find for the Euro Area.

In the case of WAEMU, two countries (Ivory Coast and Burkina Faso) have a better performance than the average of EMU12, concerning synchronization of business cycles with the aggregate of the unions. The remaining WAEMU members fall in the third quadrant.

Overall, this section confirms, for the euro-pegging period, the previous findings of Bayoumi and Ostry (1997) obtained for a period when the CFA francs were pegged to the French franc. Based on criteria (i) and (iii) of Alesina and Barro (2002), our results show that the current composition of both WAEMU and CAEMC does not conform to the theory of optimal currency areas. This is also in line with Bénassy-Quéré and Coupet (2005), who, using a different approach concluded that neither the WAEMU nor the CAEMC are optimum areas. 
A difference between CAEMC and WAEMU should, however, be underlined. While in Figure 5 the combination of the two criteria leads to scattered points along the vertical axis, in Figure 4 we can define a cluster of countries from which only Benin and Guinea-Bissau are excluded. Visual inspection thus clearly tells us that the CAEMC does not receive any support at all from the OCA theory. The same cannot openly be said for a narrower WAEMU.

\section{Conclusions and final remarks}

This paper has assessed the adequacy of the exchange rate regimes of sixteen African countries that are pegged to the euro since the inception of the new European currency. We did it in two steps. In the first, we have appraised the adequacy of the euro as the anchor currency. The results found in the first step led us to the second one, in which we have checked whether the grouping of countries in WAEMU and in CAEMC is appropriate or not. These issues have been empirically addressed using the OCA criteria highlighted in Alesina and Barro (2002), and using as a benchmark the performance of Euro Area countries.

Regarding the conclusions reached, the first one is that the peg to the euro has granted the sixteen countries a good inflation performance. In contrast to what happened in most African countries and in sub-Saharan Africa as a whole, inflation rates in most of the countries analyzed did not markedly differ from the low rates observed in the Euro Area. Because this conclusion does not imply that the euro has been the right anchor (as pegging to another low inflation currency or currency-basket of currencies could yield a similar inflation performance), we went on to study trade integration and business cycle synchronization. This investigation led us to a second conclusion.

Our second conclusion is that the euro has not been an adequate anchor for most of the African countries that are currently pegged to the European currency. The only clear exception is Cape Verde. The additional finding that the US dollar is not a superior alternative to the euro paves the way for further research on the basket of currencies recommended for these countries to peg, a task which is beyond the scope of this paper. 
In prospect, the inadequacy of the euro as anchor currency could lead to problems of sustainability of the fixed exchange-rate regimes of these African countries. Such a scenario has recently been voiced by Coleman (2008), who foresaw difficulties if the current parities were to be maintained. However, others have been more optimistic about their sustainability, in view of the specificities of the CFA arrangements that may act as shock absorbers, namely through the financial support provided by the French treasury - see e.g. Yehoue (2007).

Given the conclusions regarding the peg to the euro and in view of how WAEMU and CAEMC were formed, we have also assessed whether each monetary union receives support from the OCA theory. This led to the third and last conclusion of the paper. Overall, none of the two CFA monetary unions shows trade-intensity and cyclicalsynchronization performances that conform to the requirements of an optimal currency area. Even if we disregard intra-union trade, we still find no support for CAEMC due to the idiosyncratic business cycles of its members; in contrast, there is a wide group of WAEMU countries whose business cycles can be managed with a common monetary policy.

As a final remark, two caveats are in order. First, our data are rather limited, as we could only use annual observations for a relatively short period - the 10 year period of the peg to the euro. A richer dataset would allow for a refinement of the econometric approach and for more robust results. Second, our conclusions are based only on economic criteria and, more specifically, on a sub-set of the OCA criteria. Considering other economic criteria - either within or outside the OCA theory, e.g., international cooperation and development support - could lead to somewhat different conclusions. And, a fortiori, considering other dimensions, such as the political one, the current arrangements may well receive support. Investigation of other economic or noneconomic issues involving the choice of the exchange rate regime is, however, beyond the scope of this paper. 


\section{References}

Alesina, Alberto; Robert Barro (2002), "Currency Unions", Quarterly Journal of Economics, Vol. 107, No. 2, pp. 409-436.

Alesina, Alberto; Robert Barro; Silvana Tenreyro (2002), "Optimal Currency Areas", NBER Macroeconomics Annual, Vol. 17, pp. 301-345.

Artis, Michael; Massimiliano Marcellino; Tommaso Proietti (2004), "Dating the Euro Area Business Cycle", in Lucrezia Reichlin (Ed.) The Euro Area Business Cycle: Stylized Facts and Measurement Issues, Centre for Economic Policy Research (CEPR), London, pp. 7-34.

Bayoumi, Tamim; Jonathan Ostry (1997), "Macroeconomic Shocks and Trade Flows within Sub-Saharan Africa: Implications for Optimum Currency Arrangements", Journal of African Economies, Vol. 6, No. 3, pp. 412-444.

Bénassy-Quéré, Agnès; Maylis Coupet (2005), "On the Adequacy of Monetary Arrangements in Sub-Saharan Africa", The World Economy, Vol. 28, No. 3, pp. 349-373.

Blanchard, Olivier; Danny Quah (1989), “The Dynamic Effects of Aggregate Demand and Supply Disturbances", The American Economic Review, Vol. 79, No. 4, pp. 655-673.

Bleaney, Michael; David Fielding (2002), "Exchange rate regimes, inflation and output volatility in developing countries", Journal of Development Economics, Vol. 68, No. 1, pp. 233-245.

Buigut, Steven (2006), "Monetary Integration Initiatives in Eastern and Southern Africa (ESA): Sorting the Overlapping Membership”, International Finance, Vol. 9, No. 3, pp. 295-315.

Buigut, Steven; Neven Valev (2005), "Is the Proposed East African Monetary Union and Optimal Currency Area? A Structural Vector Autoregression Analysis", World Development, Vol. 33, No. 12, pp. 2119-2133. 
Buigut, Steven; Neven Valev (2006), "Eastern and Southern Africa Monetary Integration: A Structural Vector Autoregression Analysis", Review of Development Economics, Vol. 10, No. 4, pp. 586-603.

Carmignani, Fabrizio (2009), "Endogenous Optimal Currency Areas: the Case of the Central African Economic and Monetary Community", Journal of African Economies, Vol. 19, No. 1, pp. 25-51.

Carrère, Céline (2004), "African Regional Agreements: Impact on Trade with or without Currency Unions", Journal of African Economies, Vol. 13, No. 2, pp. 199-239.

Coleman, Simeon (2008), "Estimating Equilibrium Real Exchange Rates in the Franc Zone", Journal of African Economies, Vol. 17, No. 4, pp. 600-634.

De Haan, Jakob; Robert Inklaar; Richard Jon-A-Pin (2008), "Will Business Cycle in the Euro Area Converge? A Critical Survey of Empirical Research", Journal of Economic Surveys, Vol. 22, No. 2, pp. 234-273.

Debrun, Xavier; Paul Masson; Catherine Pattillo (2003), "West African Currency Unions: Rationale and Sustainability?", CESifo Economic Studies, Vol. 49, No. 3, pp. 381-413.

Debrun, Xavier; Paul Masson; Catherine Pattillo (2005), "Monetary Union in West Africa: Who Might Gain, Who Might Lose, and Why?", The Canadian Journal of Economics, Vol. 38, No. 2, pp. 454-481.

Debrun, Xavier; Paul Masson; Catherine Pattillo (2010), "Should African Monetary Unions be Expanded? An Empirical Investigation of the Scope for Monetary Integration in Sub-Saharan Africa", International Monetary Fund Working Paper, No. WP/10/157.

Fielding, David (2005), "What can the European Central Bank learn from Africa?" World Institute for Development Economic Research Policy Brief, No. 4.

Fielding, David; Kevin Lee; Kalvinder Shields (2004), "The Characteristics of Macroeconomic Shocks in the CFA Franc Zone", Journal of African Economies, Vol. 13, No. 4, 488-517. 
Frankel, Jeffrey (1999), "No Single Currency Regime Is Right For All Countries Or At All Times", Essays in International Finance, No. 215, Princeton University.

Giavazzi, Francesco; Marco Pagano (1988), “The advantage of tying one's hands: EMS discipline and central bank credibility", European Economic Review, Vol. 32, No. 5, pp. 1055-1075.

Hallet, Martin (2008), "The role of the euro in Sub-Saharan Africa and in the CFA franc zone”, European Economy - Economic Paper No. 347, European Commission.

Hodrick, Robert; Edward Prescott (1997), "Postwar U.S. Business Cycles: An Empirical Investigation”, Journal of Money, Credit and Banking, Vol. 29, No. 1, pp. 1-16.

Hoffmaister, Alexander; Jorge Roldós; Peter Wickham (1998), "Macroeconomic Fluctuations in Sub-Saharan Africa”, IMF Staff Papers, Vol. 45, No. 1, pp. 132160.

Houssa, Romain (2008), "Monetary union in West Africa and asymmetric shocks: A dynamic structural factor model approach", Journal of Development Economics, Vol. 85, No. 1-2, pp. 319-347.

Khamfula, Yohame; Harry Huizinga (2004), "The Southern African Development Community: suitable for a monetary union?", Journal of Development Economics, Vol. 73, No. 2, pp. 699-714.

Karras, Georgios (2006), "Is Africa an Optimum Currency Area? A Comparison of Macroeconomic Costs and Benefits", Journal of African Economies, Vol. 16, No. 2, pp. 234-258.

Kose, M. Ayhan; Raymond Riezman (2001), "Trade Shocks and Macroeconomic Fluctuations in Africa", Journal of Development Economics, Vol. 65, No. 1, pp. $55-80$.

Lamine, Baudouin (2006), "Monetary and exchange-rate agreements between the European Community and Third Countries", European Economy - Economic Papers, No. 255, European Commission. 
Longo, Robert; Khalid Sekkat (2004), "Economic Obstacles to Expanding Intra-African Trade", World Development, Vol. 32, No. 8, 1309-1321.

Masson, Paul (2008), "Currency Unions in Africa: Is the Trade Effect Substantial Enough to Justify their Formation?", The World Economy, Vol. 31, No. 5, pp. 533-547.

Masson, Paul; Catherine Pattillo (2001), "Monetary Union in West Africa (ECOWAS): Is It Desirable and How Could It Be Achieved?", International Monetary Fund Occasional Paper, No. 204.

Masson, Paul; Catherine Pattillo (2004a), “A Single Currency for Africa?”, Finance \& Development, Vol. 41, No. 4, pp. 9-15.

Masson, Paul; Catherine Pattillo (2004b), The Monetary Geography of Africa, Washington, DC: Brookings Institution Press.

Meissner, Cristopher; Nienke Oomes (2009), "Why do countries peg the way they peg? The determinants of anchor currency choice", Journal of International Money and Finance, Vol. 28, No. 3, pp. 522-547.

Mongelli, Francesco (2005), "What is European Economic and Monetary Union Telling us About the Properties of Optimum Currency Areas?", Journal of Common Market Studies, Vol. 43, No. 3, pp. 607-635.

Rand, John; Finn Tarp (2002), "Business Cycles in Developing Countries: Are They Different?", World Development, Vol. 30, No. 12, pp. 2071-2088.

Ravn, Morten; Harald Uhlig (2002), “On Adjusting the Hodrick-Prescott Filter for the Frequency of Observations" The Review of Economics and Statistics, Vol. 84, No. 2, pp. 371-376.

Rose, Andrew (2000), “One money, one market: the effect of common currencies on trade” Economic Policy, Vol. 15, No. 30, pp. 7-46.

Shortland, Anja; David Stasavage (2004), "What Determines Monetary Policy in the Franc Zone? Estimating a Reaction Function for the BCEAO, Journal of African Economies, Vol. 13, No. 4, pp. 518-535. 
Tapsoba, S. Jules-Armand (2009), “Trade Intensity and Business Cycle Synchronicity in Africa", Journal of African Economies, Vol. 18, No. 2, pp. 287-318.

Tavlas, George (2009), "The Benefits and Costs of Monetary Union in Southern Africa: A Critical Survey of the Literature", Journal of Economic Surveys, Vol. 23, No. 1, pp. 1-43.

Tsangarides, Charalambos; Mahvash Qureshi (2008), "Monetary Union Membership in West Africa: A Cluster Analysis", World Development, Vol. 36, No. 7, pp. 1261-1279.

Van den Boogaerde, Pierre; Charalambos Tsangarides (2005), "Ten Years After the CFA Franc Devaluation: Progress Toward Regional Integration in the WAEMU”, International Monetary Fund Working Paper, No. WP/05/145.

Veyrune, Romain (2007), "Fixed Exchange Rare and the Autonomy of Monetary Policy: The Franc Zone Case”, International Monetary Fund Working Paper, No. WP/07/34.

Yehoue, Etienne (2006), "On the patterns of currency blocs in Africa", Journal of African Development, Vol. 1, No.1, pp. 39-86.

Yehoue, Etienne (2007), "The CFA Arrangements - More than Just an Aid Substitute?", International Monetary Fund Working Paper, No. WP/07/19. 


\section{Annex}

Table A.1. International trade in goods, 2003-08 ${ }^{\text {(a) }}$

\begin{tabular}{lccccc}
\hline \multirow{2}{*}{ Country/Region } & \multicolumn{3}{c}{ Openness (\% of GDP) } & \multicolumn{2}{c}{$(\%)$} \\
& EMU (I) & US(II) & World (III) & (I)/(III) & (II)/(III) \\
\hline Cape Verde & 17.9 & 1.0 & 23.9 & 74.9 & 4.2 \\
Comoros & 7.4 & 0.6 & 14.8 & 50.0 & 4.1 \\
WAEMU ${ }^{\text {(b) }}$ & 8.6 & 1.3 & 26.2 & 32.8 & 5.0 \\
Benin & 6.8 & 2.0 & 20.5 & 33.2 & 9.8 \\
Burkina Faso & 3.9 & 0.2 & 16.0 & 24.4 & 1.3 \\
Guinea-Bissau & 7.3 & 0.9 & 19.3 & 37.8 & 4.7 \\
Ivory Coast & 12.4 & 2.7 & 38.1 & 32.5 & 7.1 \\
Mali & 4.7 & 0.3 & 26.0 & 18.1 & 1.2 \\
Niger & 6.0 & 1.5 & 20.4 & 29.4 & 7.4 \\
Senegal & 11.1 & 0.7 & 27.2 & 40.8 & 2.6 \\
Togo & 16.3 & 2.1 & 41.9 & 38.9 & 5.0 \\
\hline CAEMC ${ }^{\text {(b) }}$ & 9.1 & 9.8 & 34.4 & 26.5 & 28.5 \\
Cameroon & 10.7 & 1.2 & 17.3 & 61.8 & 6.9 \\
Central African Republic & 5.6 & 0.9 & 11.7 & 47.9 & 7.7 \\
Chad & 2.5 & 11.3 & 35.0 & 7.1 & 32.3 \\
Equatorial Guinea & 16.2 & 16.8 & 55.9 & 29.0 & 30.1 \\
Gabon & 10.2 & 13.3 & 35.2 & 29.0 & 37.8 \\
Republic of Congo & 9.4 & 15.6 & 51.1 & 18.4 & 30.5 \\
\hline
\end{tabular}

Sources: - EMU12: Eurostat, (accessed in June 2010) available at http://epp.eurostat.ec.europa.eu/portal/page/portal/external_trade/data/database and at http://epp.eurostat.ec.europa.eu/portal/page/portal/national_accounts/data/database

- Trade in goods with the US: U.S. Census Bureau, Foreign Trade Division, Data Dissemination Branch, Washington, D.C. 20233, available at http://www.census.gov/foreign-trade/balance/ (accessed in September 2010).

- Remaining data (accessed in June 2010):

- Trade in goods with the EMU: Eurostat, available at http://epp.eurostat.ec.europa.eu/portal/page/portal/; total trade in goods: United Nations Conference on Trade and Development (UNCTAD), Handbook of Statistics on line, available at http://www.unctad.org/Templates/Page.asp?intItemID=1890\&lang=1.

- GDP: International Monetary Fund, World Economic Outlook database, April 2010, available at http://www.imf.org/external/pubs/ft/weo/2010/01/weodata/weoselgr.aspx.

Notes: (a) This table differs from Table 2 in the main text with two respects: (i) due to lack of homogeneous information on the trade in services with the U.S., we report international trade only in goods; (ii) once we use only trade in goods we are able to update the results until 2008. As shown in Table 3, and excluding Cape Verde and Comoros, trade in goods represents most of international trade of the countries in the sample.

(b) Simple (un-weighted) average of the ratio of openness across the member countries. 
Table A.2. Correlations with the U.S. business cycle, 1999-2008

\begin{tabular}{lc}
\hline \multicolumn{1}{c}{ Country/Region } & Correlation coefficient \\
\hline Cape Verde & 0.458 \\
\hline Comoros & -0.379 \\
\hline WAEMU: & -0.751 \\
Benin & 0.296 \\
Burkina Faso & -0.243 \\
Guinea-Bissau & 0.342 \\
Ivory Coast & -0.523 \\
Mali & -0.502 \\
Niger & $\mathbf{0 . 6 7 8}$ \\
Senegal & 0.507 \\
Togo & \\
CAEMC: & 0.100 \\
Cameroon & 0.357 \\
Central African Republic & 0.166 \\
Chad & -0.337 \\
Equatorial Guinea & -0.598 \\
Gabon & -0.045 \\
Republic of Congo &
\end{tabular}

Source: Authors' calculations.

Note: Values in bold are positive and statistically different from 0 at the 5 percent level of significance. 